\title{
The Competitiveness Advantage of Enterprises: A Decision Strategy
}

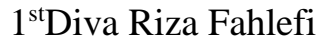 \\ Doctorate of Management Programme \\ Diponegoro University \\ Semarang, Indonesia \\ divarizafahlefi@gmail.com
}

\author{
$2^{\text {nd }}$ Farida Indriani \\ Doctorate of Management Programme \\ Diponegoro University \\ Semarang, Indonesia
}

\begin{abstract}
In today's globalized world, trade has become increasingly complex. The dependence that grows between markets and increasing competition makes it increasingly difficult to defend a company^^s market position. It is increasingly difficult for companies to maintain their competitive advantage. Companies need to make a strategy for their position and build a competitive advantage (Competitive Advantage). Because of the importance of competitive advantage for a company, it is necessary to find out about how a company determines its competitive advantage. Several previous studies stated that the entrepreneurial ability of a company (Entrepreneural Competencies) plays a very important role in determining competitive advantage (Competitive Advantage) and there are several other factors that influence competitive advantage. Therefore, this study aims to determine the research trends related to competitive advantage and how big the role of entrepreneurial competencies is to competitive advantage so that companies have superior competencies. The method used in this research is bibliometric analysis by analyzing several theories and previous studies. The findings show that several previous studies have stated that entrepreneurial competencies play a role in determining the competitive advantage of a company. Therefore, a company must find out its entrepreneurial competence so that it can find out its competitive advantage among competitors.
\end{abstract}

Keywords: Competitive Advantage, Entrepreneurial Competencies, Firm, Competition

\section{INTRODUCTION}

In today's globalized world, trade has become increasingly complex. The dependence that grows between markets and increasing competition makes it increasingly difficult to defend a company's market position. It is increasingly difficult for companies to maintain their competitive advantage. Companies are penetrating new markets and competition is becoming increasingly fierce [1]. In the market, a company does not just stand-alone. Some so many competitors are looking for other company weaknesses so that they can dominate the market position. One of the ways to increase competitiveness is by means of a competitive advantage determined by the company [1].

Therefore, companies need to make a strategy for their position and build a competitive advantage (Competitive Advantage). The company must be able to make the best use of its strengths and must meet customer needs to achieve a competitive advantage which will facilitate the elimination of competition and obtain large profits.

Because of the importance of competitive advantage for a company, it is necessary to find out how a company determines its competitive advantage. Therefore this study aims to determine the research trends related to competitive advantage and what factors influence it, as well as how the concepts have been used by several previous studies.

\section{LITERATURE REVIEW}

Kaushik Mukerjee in his research suggests that company-level scope and strategy, diversification decisions, resource deployment decisions, and company strategic reforms need to be managed for competitive advantage. Factors such as customer orientation, value chain, and culture, change management approaches contribute to the company's competitive advantage. Mukerjee said that one factor does not produce a competitive advantage but a combination of various factors affects a competitive advantage. Companies need to focus on all factors and ignore one or more of the factors that damage the company's competitive advantage [2].

In competing, every company must have good competence and performance. Hao $\mathrm{Ma}$, related the relationship between competitive advantage and performance. There are three categories according to Hao Ma. The first category is competitive advantage leads to superior performance. The second category is a competitive advantage without superior performance. And the third category is superior performance without a competitive advantage. Hao $\mathrm{Ma}$ divides competitive advantage into two types, compound competitive advantage (Compound Competitive Advantage) and discrete competitive advantage (Discrete Competitive Advantage). Multiple competitive advantages consist of price, differentiation, speed of response, flexibility, and innovation. The discrete competitive advantage consists of location, cash, exclusive offers, distribution monopoly, and managerial talent [3].

A company needs to anticipate and respond to environmental changes to ensure competitiveness and survival According to Kruehler et al [4], a company must 
be the best owner in its business portfolio and the characteristics of the parent company must match the determinants of business success and their needs. To gain and maintain a competitive advantage, companies need to focus on the factors highlighted in the proportion of research and take a proactive approach to ensure survival in a highly competitive market.

Research conducted by Yakubu Salisu and Lily Julienti Abu Bakar [5] suggested that the factors that affect the company's ability to increase competitive advantage are innovation capability, learning capability, management capability, marketing capability. ), Relational Capability, and technological capabilities (Technological Capability).

Entrepreneurial Competencies have been identified as certain groups of competencies that are relevant to the successful implementation of entrepreneurship [6]. Entrepreneurship like that is often associated with small and new business developments [7]. In a study conducted by Bartlett and Goshal[8], there are three categories of competencies between attitudes, knowledge, and skills. Stuart and Lindsay [9] define similar things as skills, knowledge, and personal characteristics of a person. Entrepreneurial competencies consist of opportunity recognizing competencies, strategic competencies, organizing competencies, relationship competencies, conceptual competencies, and commitment competencies. profitability.

\section{METHOD}

The method used in this research is a bibliometric analysis by analyzing several theories and previous studies. Bibliometric analysis or what is often referred to as a literature review is a method that summarizes a collection of writings from several valid sources on a topic [10]. Bibliometric analysis or commonly referred to as scientometrics is part of the research evaluation method and from the various literature that has been produced, it is possible to use a separate method [11].

This research will explain Entrepreneurial Competencies which will mediate competitive advantage (Competitive Advantage). Entrepreneurial competencies consist of opportunity recognizing competencies, strategic competencies, organizing competencies, relationship competencies, conceptual competencies, and commitment competencies.

\section{RESULTS AND DISCUSSION}

\section{A. Concept of Competence and Competitive Advantage}

Competence in an organization can be broadly classified as employee level competencies and organizational level competencies. According to Robert L. Cardy and Selvarajan [12], because organizational level competencies are embedded in employee-level competencies, it is more important to identify employeelevel competencies to achieve competitive advantage. Kennedy and Dresser [13] define competence as something owned by a company that contributes to the company's success. In their book, Turner and Crawford [14] classify competencies into two categories, namely individual competences and company competencies. Personal competencies are owned by individuals and include characteristics such as knowledge, skills, abilities, experience, and personality performance. Company competence belongs to the organization of the company and is an embedded and structured process that tends to reside within the organization even when individuals are away. The characteristics of the company can determine the type of personal competence most suitable in the organization.

The concept of competitive advantage has been around for a very long time. Ansoff defines competitive advantage as isolated characteristics or certain traits that provide a strong competitive position. A different thing is expressed by Porter which states that competitive advantage comes from the company's ability to create superior value for its buyers. Superior value comes from bidding at a lower price than a competitor for equivalent benefits or that provides more unique benefits than others. Meanwhile, Sigalas and Pekka-Economou identified two streams of conceptual demarcation of competitive advantage. The first stream defines competitive advantage in terms of performance, e.g. high relative profitability, above-average returns, the benefit-cost gap, superior financial performance, economic returns, positive profit differentials over opportunity costs, and cross-sectional differentials in the spread between product market demands. and the marginal cost of the second stream defines competitive advantage in its determinants, for example, the specific nature of individual product markets, cost leadership, differentiation, location, technology, product features, and a particular set of firm resources and capabilities.

\section{B. Entrepreneurial Competencies}

Entrepreneurial competence has six main areas. The six main areas, among others, are Opportunity Recognition Competencies, Relationship Competencies, Conceptual Competencies, Organizing Competencies, Strategic Competencies, and Commitment Competencies. Recognizing opportunities by identifying and selecting the right opportunities (Opportunity Recognition Competencies) for the business is the most important ability for an entrepreneur. An entrepreneur must be observant with the opportunities and resources available so that they recognize gaps and can integrate the opportunities or resources they have. In developing Entrepreneurial potential with resources and capabilities, entrepreneurs must take advantage of opportunities in business.

Relationship competencies are concerned with person-toperson or individual-to-group interactions. Relationship Competencies relate to building cooperation and trust, utilization and communication, persuasive communication, and interpersonal skills. When networking with other people, entrepreneurs will have the opportunity to acquire and strengthen them in business. An entrepreneur who has this competency will produce a competitive advantage and improve company performance.

Conceptual competencies are related to conceptual abilities that are reflected in entrepreneur behavior, such as making decisions automatically about business opportunities or absorbing and understanding complex information for company improvement. Conceptual Competencies demonstrate cognitive processes in 
decision-making skills, the ability to weigh risks, think analytically, creatively, and innovatively by minimizing risk. Knowledge (Conceptual Competencies) is the basis of competitive advantage in explaining how a business can be established, developed, maintained, and transfers this knowledge into business.

Organizing competencies determine the mode in which the business operates and works. In Organizing Competencies, entrepreneurs must have the ability to lead, command, coordinate, control, manage, monitor, delegate, motivate, and manage internal and external business resources. Organizing Competencies will allow the allocation of responsibilities for various functions and processes between branches, departments, workgroups, and individuals. Changes in structure and increasing competitive pressures cause companies to focus on these competencies which will support their competitive advantage [15]. According to Zainol and Abdullah [16]. Organizing Competencies is an ability that presents a sustainable competitive advantage where competitive advantage will contribute to the company's performance in the long term.

Strategic competencies relate to the ability of entrepreneurs to develop their business vision. The company develops its vision by formulating and implementing strategies, planning, setting clear goals and standards, estimating the finance needed to implement strategies and thoughts, and creating ideas [17]. Based on the interaction of strategic competencies, competitive advantage refers to real advantages,

Companies that strive to achieve long-term goals with strong dedication will tend to have committed competencies. To sustain a competitive advantage, companies need to give full commitment when carrying out a job. The company should make a special effort to ensure that customers are satisfied with their work and results.

\section{Competitive advantage}

Competitive advantage can be seen from various theories. Initially, two theories underlie the theory of competitive advantage, namely Market-Based View (MBV) and Resources-Based View (RBV). KnowledgeBased View and Capability-Based View theories are derived from Resources-Based View theory. In the Market-Based View theory, industry and external market factors are the main determinants of company performance [18]. This is because the sources of firm value are embedded in a competitive situation that characterizes the end product's strategic position. Strategic position is the unique set of activities of a company that is different from its competitors. The strategic position of a company is determined by how it performs activities similar to other companies but in different ways. The focus of this Market-Based View theory is on the company environment and external factors. Ling Wang [19], examined that company performance significantly depends on the industrial environment. Ling Wang views strategy in the context of the industry as a whole and the company's position in the market against its competitors. In formulating strategy, companies usually make an overall assessment of their competitiveness through an external environmental assessment based on five strengths. The five forces include barriers to entry, the threat of substitution, bargaining power of suppliers, bargaining power of buyers, and competition between competitors. This five forces model allows companies to analyze their industry situation in a structured way. However, this model has limitations. Porter's model assumes the classical perfection of markets with a static market structure that is impossible to find in today's dynamics. Prahalad and Hamel [20] said that competitive advantage based on resources (Resource-Based View) and capabilities (Capability-Based View) is more important than just based on market position (Market-Based View).

Furrer et al [21] suggest that the focus of the MarketBased View (MBV) has changed to the internal structure of the company, with its resources (Resource-Based View) and capabilities (Capability-Based View). Wernerflet [22] views a company as a set of assets or resources that are semi-permanently tied to the company. Meurut Barney [23] company resources are the main source of its competitive advantage. Ramos-Rodriguez and Ruiz-Navarro [24] in their study said that the most prominent contribution to strategic discipline is the Resouce-Based View strategy. Miller and Shamsie [25] classified resources into two categories, namely propertybased and knowledge-based. According to Barney [23] in addition to the general resources of a company, there are additional resources, such as physical capital resources, human capital resources, and organizational capital resources. Barney also added that companies that can utilize resources to implement competitive strategies will achieve a competitive advantage. Maier and Remus [26] use the term 'Resource Strategy' and define three steps. These steps include competency creation, competency realization, and transaction competence. Competency creation defines and analyzes markets, products, and services. The realization of competence involves the implementation of services, procurement, and production. Competency transactions involve market logistics, order fulfillment, and maintenance.

Hamel and Prahald [27] argue that knowledge, intellectual assets, and competencies are the main drivers of superior performance in the information age. Knowledge (Knowledge-Based View) is the most important resource of a company. According to him, material resources will decrease when used in the company, while knowledge assets will increase with use. Zack [28] divides organizational knowledge into three categories, namely core knowledge, advanced knowledge, and innovative knowledge. Companies with innovative knowledge will have a competitive advantage over their rivals. Companies with innovative knowledge can introduce innovative products or services to customers that have the potential to help them lead the market.

The importance of capability for a company. The company will get a competitive advantage from its capabilities. Zack [21] explains that the ability to learn and create new knowledge (Capability-Based View) is important to gain a competitive advantage. 


\section{How Entrepreneurial Competence Mediates Competitive Advantage}

Entrepreneurial competence is an internal factor that a company has. Where based on the theory stated above that internal factors or resources (Resource-Based View) are the main sources of competitive advantage. Quantitative research conducted by Zainol and Abdullah [16] concluded that Entrepreneurial Competencies have a significant effect on competitive advantage (Competitive Advantage). In his research, Opportunity Recognition Competency, Conceptual Competency, and Organizing Competency with Competitive Advantage have a p-value of less than 0.05 which indicates a significant relationship. Meanwhile, the p-value between Relationship Competency, Strategic Competency, and Commitment Competency is more than 0.05 which indicates that the relationship is positive but not significant. In this finding, several entrepreneurial competencies (Entrepreneurial Competencies) mediate the competitive advantage (Competitive Advantage) in part. The entrepreneurial competencies are Opportunity Recognition Competency, and Organizing Competency. Meanwhile, Conceptual Competency fully mediates competitive advantage.

\section{CONCLUSION}

From the description of the existing findings, companies must identify their competencies in their competitive advantage, which is a value creation strategy that cannot be done and duplicated by competitors. Companies must have valuable, rare, and hard to replicate business resources. Companies also need to know the knowledge and capabilities that will give them a competitive advantage.

\section{ACKNOWLEDGMENT}

We thank our colleagues from Doctorate Program of Diponegoro University who become of the author affiliation.

\section{REFERENCES}

[1] Vrchota, M. M. (2014). Influence of Competitive Advantage on Formulation Business Strategy. Procedia Economics and Finance.

[2] Mukerjee, K. (2016). Factors That Contribute Towards Competitive Advantage : A Conceptual Analysis. IUP Journal of English Studies

[3] HaoMa. (2000). Competitive advantage and firm performance. Competitiveness Review An International Business Journal incorporating Journal of Global Competitiveness , 15-32.

[4] M kruehler, U. P. (2012). How to Assess the Corporate Parenting Strategy? A Conceptual Answer. Journal of Business Strategy, 417.

[5] Bakar, Y. S. (2019). Determinants of Competitive Advantage for Small and Medium Enterprises in Developing Economies : Capabilities-Based Perspective. Asia Proceedings of Social Science.

[6] Rowley, S. M. (2010). Entrepreneurial Competencies : a Literature Review and Development Agenda. International Journal of Entrepreneurial Behaviour and Research.

[7] Nuthall, P. (2006). Determining the Important Management Skill Competencies : The Case of Family Farm Business in New Zealand. Agricultural Systems , 429-450.
[8] Ghoshal, C. B. (1997). The Myth of The Generic Manager : New Personal Competencies For New Management Roles. California Management Review.

[9] Lindsay, R. S. (1997). Beyond the Frame of Management Competencies : towards a contextually embedded framework of managerial competence in organizations. Journal of European Industrial Training, 26-33.

[10] Knopf, J. W. (2006). Doing a Literature Review. Political Science and Politics, 39(1), 127-132.

[11] Ellegaard, O., \& Wallin, J. A. (2015). The bibliometric analysis of scholarly production: How great is the impact? Scientometrics, 105(3), 1809-1831.

[12] T.T.Selvarajanb, R. L. (2006). Competencies: Alternative frameworks for competitive advantage. Business Horizons, 235 245.

[13] Kennedy, P. W., \& Dresser, S. G. (2005). Creating a competencybased workplace. Benefits \& Compensation, 42(2), 19-23

[14] D. Turner and M. Crawford, "Managing Current and Future Competitive Performers: The Role of Competency," In: G. Hamel and A. Heene., Eds., Competency- Based Competition, Strategic Management Series, Wiley, 1994, pp.241-254

[15] Wen-Cheng, Chien-Hung \& Ying-Chien, 2011. Types of Competitive Advantage and analysis. International Journal of Business and Management Vol. 6, No. 5.

[16] Zainol, N. R., Al-Mamun, A. (2018). Entrepreneurial competency, competitive advantage and performance of informal women microentrepreneurs in Kelantan, Malaysia. Journal of Enterprising Communities: People and Places in the Global Economy, 12(3), 299-321.

[17] Kaur, Hardeep. Bains, Anupama. (2013).Understanding The Concept Of Entrepreneur Competency. Journal of Business Management \& Social Sciences Research (JBM\&SSR) ISSN No: 2319-5614 Volume 2, No.11, November 2013

[18] Peteraf, M.A. and Bergen, M.E. (2003) Scanning Dynamic Competitive Landscapes: A Market-Based and Resource-Based Framework. Strategic Management Journal, 24, 1027-1041.

[19] Wang, H. (2014). Theories for competitive advantage. In H. Hasan (Eds.), Being Practical with Theory: AWindow into Business Research (pp. 33-43). Wollongong, Australia: THEORI

[20] Prahalad, C.K. and Hamel, G. (1990) The Core Competence of the Corporation. Harvard Business Review, 79-91.

[21] Olivier Furrer, H. T. (2008). The Structure and Evolution of the Strategic Management Field: A Content Analysis of 26 Years of Strategic Management Resear. International Journal of Management Reviews, Vol. 10, Issue 1, , 1-23.

[22] Wernerfelt, B. J. S. m. j. (1984). A resource - based view of the firm. Strategic Management Journal, 5(2), 171-180.

[23] Barney, J. J. J. o. m. (1991). Firm resources and sustained competitive advantage. Journal of Management, 17(1), 99-120.

[24] Ramos-Rodríguez, A. R. (2004). Changes in The Intellectual Structure of Strategic Management Research. Strategic Management Journal 25(10), 981-1004.

[25] Miller, D. and Shamsie, J. (1996) The Resource-Based View of the Firm in Two Environments: The Hollywood Film Studios from 1936 to 1965 . Academy of Management Journal, 39, 519-543.

[26] Maier, R\& Remus, U2002, 'Defining process-oriented knowledge management strategies', Knowledge and Process Management, vol. 9, no.2, pp.103-118.

[27] Hamel, G. and C. K. Prahalad, (1994). Competing for the Future. Harvard Facilitation and support School, Boston, London.

[28] Zack, M. (1999). 'Developing a knowledge strategy'. California Management Review, 41, 125-144. 